\title{
Identification of Proteins Involved in Toxin Production by Pseudomonas glumae
}

\author{
Fumihiko SUZUKI*, Yafeng ZHU*,**, Hiroyuki SAWADA* and Izumi MATSUDA ${ }^{*, * * *}$
}

\begin{abstract}
Two acidic proteins involved in toxoflavin production by Pseudomonas glumae, causal agent of rice seedling rot and grain rot, were identified. Non-toxigenic $\left(\mathrm{Tox}^{-}\right)$Tn5 mutants which did not produce a yellow pigment, were avirulent to rice plants. When proteins from wild-type and Tox ${ }^{-}$strains were separated by two-dimensional polyacrylamide gel electrophoresis (2D-PAGE), two acidic proteins, designated as TRP-1 and TRP-2, were found in the wild-type but not Tox ${ }^{-}$strains. The synthesis of TRP-1 and -2 was confined to the late exponential phase of culture growth, corresponding to toxoflavin production during the late exponential to early stationary phases of culture growth. The anti-TRP1 antibody reacted with a single protein band of about $30 \mathrm{kDa}$ only on blots of SDS-PAGE separations of those $P$. glumae and P. gladioli strains able to produce toxoflavin.
\end{abstract}

(Received June 23, 1997 ; Accepted November 13, 1997)

Key words : Pseudomonas glumae, toxoflavin-related proteins.

\section{INTRODUCTION}

Pseudomonas glumae Kurita and Tabei causes rice seedling rot in nursery boxes and grain rot in the field after heading. The bacterium produces a yellow substance which has been identified as the phytotoxin toxoflavin ${ }^{12)}$

Toxoflavin, a yellow crystalline solid isolated in 1933 from Pseudomonas cocovenenans, was responsible for certain fatal food poisonings among the natives of $\mathrm{Java}^{16,17)}$. Later, the antibiotic xanthricin from a Streptomyces species was identified as toxoflavin ${ }^{8}$. However, as a phytotoxin, this substance is produced only in $P$. glumae and several strains of $P$. gladioli.

The toxin reduces the growth of both leaves and roots of rice seedlings ${ }^{5,12}$, and produces a chlorotic spot on thier leaves. Added to this, Tox ${ }^{-}$strains spontaneously occurring during the course of subculture, do not cause disease. Therefore, toxoflavin synthesis appears to play an important role in lesion development of $P$. glumae on rice plants.

One objective of the present study was to isolate non-toxigenic mutants of $P$. glumae by transposon mutagenesis and to determine the role of toxin production in virulence. In addition to this, we speculated that wild-type and $\mathrm{Tox}^{-}$strains might differ in the production of proteins, which are primary gene products, and that wildtype-specific proteins may contribute to toxin production. If we could identify the proteins related to toxoflavin synthesis, DNAs encoding the Tox genes could possibly be cloned using advanced gene manipulation techniques. For this purpose, we applied twodimensional polyacrylamide gel electrophoresis (2DPAGE) and compared the patterns of proteins synthesized in wild-type and Tox- mutants.

\section{MATERIALS AND METHODS}

Bacterial strains, plasmids and media The sources of bacterial strains and plasmids and their relevant characteristics are shown in Table $1 . P$. glumae and other pseudomonads were routinely grown in PPGA medium $^{10)}$ or King's B medium ${ }^{6)}$ at $28^{\circ} \mathrm{C}$ or $37^{\circ} \mathrm{C}$. Escherichia coli was grown in $\mathrm{LB}$ medium ${ }^{9)}$ at $28^{\circ} \mathrm{C}$ or $37^{\circ} \mathrm{C}$. Antibiotics were added to the media at the following concentrations: for $E$. coli strains: kanamycin $(\mathrm{Km})$, $20 \mu \mathrm{g} / \mathrm{ml}$; and for P. glumae : rifampicin (Rif), $20 \mu \mathrm{g} / \mathrm{ml}$. Antibiotics were purchased from Sigma Chemical Co., St. Louis, MO.

Transposon Tn5 mutagenesis in P. glumae and identification of Tox $^{-}$mutants Biparental conjugation was used for Tn5 insertion into strains $P$. glumae. pSUP1021 ${ }^{15)}$ was transferred from $E$. coli strain S17-1 ${ }^{14)}$ to $P$. glumae PG9501 by growing the donor and recipient together on $\mathrm{LB}$ agar plates at $28^{\circ} \mathrm{C}$ for $12 \mathrm{hr}$, selecting for the transconjugant phenotype (rifampicin resistance $\left[\mathrm{Rif}^{\mathrm{r}}\right]$, kanamycin resistance $\left.\left[\mathrm{Km}^{\mathrm{r}}\right]\right) . \mathrm{Km}^{\mathrm{r}}$

\footnotetext{
* National Institute of Agro-Environmental Science, Tsukuba 305-8604, Japan 農業環境技術研究所

** Present address : DNAVEC Research Inc., Tsukuba 305-0856, Japan 現在：(株)ディナベック研究所

*** Present address : National Agricultural Research Center, Tsukuba 305-8666, Japan＼cjkstart現在：農業研究センター
} 
Table 1. Bacterial strains and plasmids

\begin{tabular}{|c|c|c|}
\hline Strain or plasmid & Relevant characteristics and origin & Source or reference \\
\hline \multicolumn{3}{|l|}{ Pseudomonas glumae } \\
\hline PG3 & Tox $^{+} \operatorname{Rif}^{r}$; Isolated from rice & This study \\
\hline PG9501 & $\mathrm{Tox}^{+} \mathrm{Rif}^{\mathrm{r}}$; Isolated from rice & This study \\
\hline PGTDM1 & PG3::Tn5 Tox ${ }^{-} \mathrm{Km}^{\mathrm{r}}$ Rifr $^{\mathrm{r}}$ & This study \\
\hline PGTDM2 & PG3::Tn5 Tox ${ }^{-} \mathrm{Km}^{\mathrm{r}}$ Rif $^{\mathrm{r}}$ & This study \\
\hline PGTDM3 & PG9501::Tn5 Tox ${ }^{-} \mathrm{Km}^{\mathrm{r}}$ Rif $^{\mathrm{r}}$ & This study \\
\hline PGTDM4 & PG9501::Tn5 Tox ${ }^{-}$Km $^{\mathrm{r}}$ Rifr $^{\mathrm{r}}$ & This study \\
\hline \multicolumn{3}{|l|}{ Pseudomonas gladioli } \\
\hline PD8726 & Tox $^{+}$; Isolated from rice & This study \\
\hline MAFF301584 & Tox $^{-}$; Isolated from Vuylstekeara spp. & MAFF \\
\hline \multicolumn{3}{|l|}{ Pseudomonas plantarii } \\
\hline MAFF301723 & Tox ${ }^{-}$; Isolated from rice & MAFF \\
\hline \multicolumn{3}{|l|}{ Escherichia coli } \\
\hline $\mathrm{S} 17-1$ & 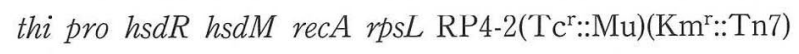 & 14 \\
\hline \multicolumn{3}{|l|}{ Plasmid } \\
\hline pSUP1021 & pACYC184::Tn5 $\mathrm{Tc}^{\mathrm{r}} \mathrm{Mob}^{+}$ & 15 \\
\hline
\end{tabular}

$\mathrm{Rif}^{\mathrm{r}}, \mathrm{Tc}^{\mathrm{r}}$, and $\mathrm{Km}^{\mathrm{r}}$ indicate resistance to rifampicin, tetracycline and kanamycin, respectively. Tox ${ }^{+}$produces toxoflavin.

survivors were replicated onto PPGA agar plates to test for toxoflavin production.

Virulence assays The bacteria were suspended in sterilized distilled water and their concentration was adjusted to about $10^{8} \mathrm{cfu} / \mathrm{ml}$. The suspension $(1 \mathrm{ml})$ was added to a glass tube where rice seedlings (cultivar; Koshihikari) were growing in soil. The seedlings were incubated at $32^{\circ} \mathrm{C}$. One week after inoculation, virulence of each isolate was estimated by assessing the severity of seedling rot.

Two-dimensional gel electrophoresis A pellet of cells was homogenized with lysis buffer ${ }^{11)}$ in an eppendorf tube and centrifuged at $15,000 \times g$ for 5 min. Fifty microliters of supernatant was subjected to 2D-PAGE according to the method described by O'Farrell ${ }^{11)}$ with slight modifications ${ }^{4}$. After electrophoresis, the proteins were detected by coomassie blue staining.

Preparation of antisera A rabbit was immunized by subcutaneous injection of the protein sample which was excised out from the gel. Two weeks after the first immunization, the rabbit was injected with weekly boost immunizations of the protein with incomplete adjuvant. The rabbit was bled at 5 weeks after the initial immunization. The serum was stored at $-80^{\circ} \mathrm{C}$.

Western blots Protein samples were transferred from the gel to polyvinylidene difluoride membranes (ATTO Co., Japan) by electroblotting. Anti-TRP1 antibody, alkaline phosphatase-conjugated secondary antibodies, and the color-substrates NBT (para-nitro blue tetrazolium chloride; Wako Pure Chemical Ltd., Japan) and BCIP (5-bromo-4-chloro-3-indoyl phosphate; Wako Pure Chemical Ltd.) were used to detect bound antigen.

\section{RESULTS}

Isolation and characterization of Tox $x^{-}$mutants Rif $^{r} \mathrm{Km}^{\mathrm{r}} P$. glumae transconjugants were obtained at

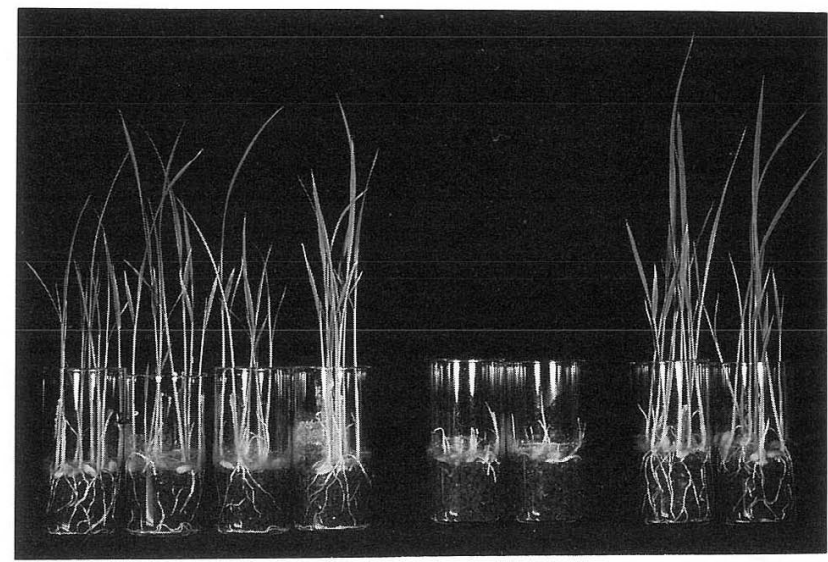
(A) (B)
(C) (D)
(E) (F)
(G) $\quad(\mathrm{H})$

Fig. 1. Virulence assays. Rice seedlings were inoculated as described in the text. Photograph of seedlings was taken 8 days after inoculation. Plants were inoculated with strains (A) PGTDM1, (B) PGTDM2, (C) PGTDM3, (D) PGTDM4, (E, F) PG9501, (G, H) water.

a frequency of $2 \times 10^{-6}$ per donor cell plated. Southern blot analysis of EcoRI-digested total genomic DNA further indicated that the insertion of Tn5 in the genome of P. glumae PG9501 was random (data not shown). More than 5000 presumptive Tn 5 mutants were screened for loss of toxin production by a lack of yellow pigment on PPGA medium agar plates. Four prototrophic Tox ${ }^{-}$ mutants were isolated from independent matings of strains PG9501 and S17-1 (pSUP1021).

None of the four Tox ${ }^{-}$mutants caused symptoms on rice seedlings (Fig. 1). The ability to cause symptoms seemed likely to be correlated with the in vitro ability to produce the yellow pigment. 


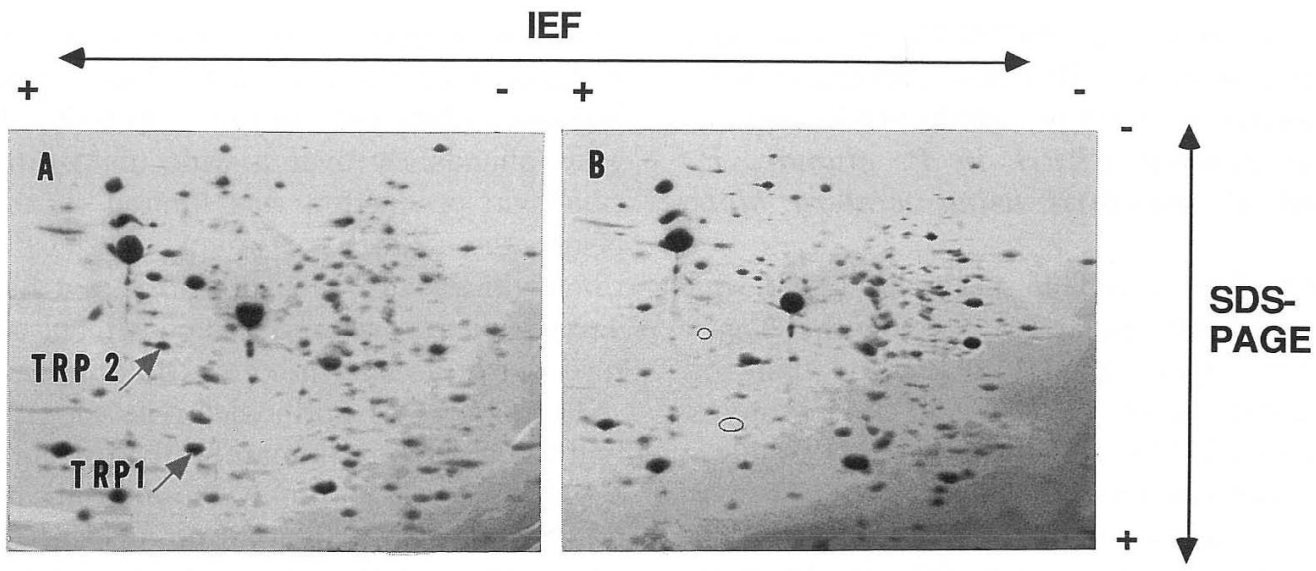

Fig. 2. 2D-PAGE patterns of $P$. glumae proteins. A, P. glumae wild-type PG9501 (arrows indicate TRP-1 and TRP-2) ; B, P. glumae Tox ${ }^{-}$mutant PGTDM1. Right to left, isoelectric focusing for first dimension; up to down, SDS-PAGE for second dimension.
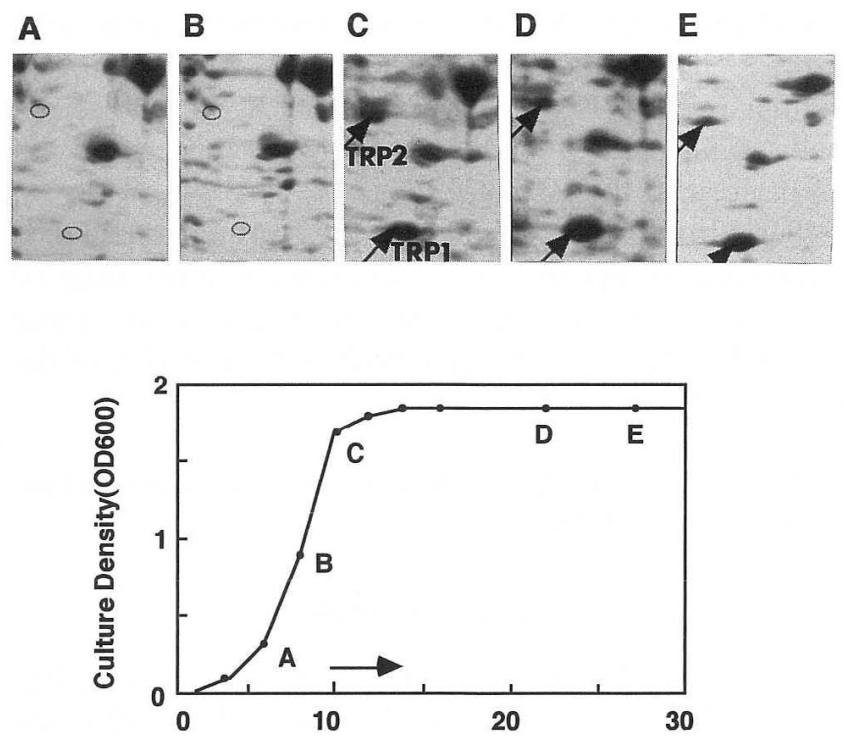

Fig. 3. Synthesis of TRP-1 and TRP-2 throughout the culture cycle of $P$. glumae. Proteins synthesized in $P$. glumae PG9501 wild-type cells during growth in King's $\mathrm{B}$ medium at $37^{\circ} \mathrm{C}$ were analyzed by 2D-PAGE. P. glumae PG9501 was grown in King's B medium at $37^{\circ} \mathrm{C}$. Growth of bacteria was monitored by measuring $\mathrm{OD}_{600}$. Point $(\mathrm{A}-\mathrm{E})$ on the growth curve indicates time at which experiments were performed : A to C, exponential phase ; $\mathrm{D}$ and $\mathrm{E}$, stastionary phase. Arrow shows when the toxin was detected in culture.

2D-PAGE patterns of proteins synthesized in wild-type and Tox ${ }^{-}$mutants

Figure 2 shows the 2D-PAGE patterns of both bacterial proteins which were detected by coomassie blue staining. The bacterial proteins were obtained from shaking cultures of King's B liquid medium incubated at $37^{\circ} \mathrm{C}$ within $24 \mathrm{hr}$. A total of about 350 polypeptide spots were identified in each pattern. The electrophoretic pattern of all but two of the polypeptide spots in Tox ${ }^{-}$ mutants was identical with those of the wild-type

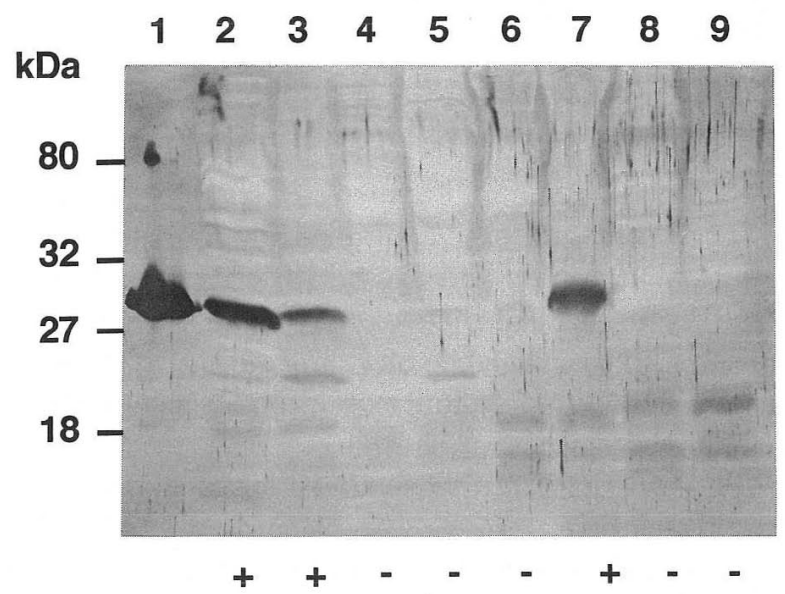

Fig. 4. Western blot of SDS-PAGE separation of proteins extracted from various strains of Pseudomonads: TRP-1 (lane 1), P. glumae wildtype PG9501 (lane 2-3), Tox mutants (lane 4-6), $P$. gladioli (lane 7), $P$. gladioli (lane 8), $P$. plantarii (lane 9). Positions of molecular mass markers are noted in the left margin $(+,-$, under the figure, indicate the ability of toxin producion).

strains. Only two appreciable differences were found in the electrophoretic patterns; a spot designated as toxoflavin-related protein-1 (TRP-1) and a spot designated as toxoflavin-related protein-2 (TRP-2) were stained intensively in wild-type strains, but not in Tox ${ }^{-}$mutants (Fig. 2). By 2D-PAGE, TRP-1 and -2 exhibited molecular mass of about $30 \mathrm{kDa}$ and $40 \mathrm{kDa}$, respectively, and isoelectric points of 5.6 and 5.4, respectively.

Comparison between the patterns of TRP-1 and -2 proteins synthesized in exponential- and stationary-phase bacterial cells

A wild-type $P$. glumae strain (PG9501) was grown in King's B liquid medium at $37^{\circ} \mathrm{C}$. Toxoflavin production was detected when the culture was in the late exponential to early stationary phases of growth which was monitored by $\mathrm{OD}_{600}$ (Fig. 3). Because TRP-1 and 
TRP-2 were detected on 2D-PAGE in the late exponential phase (Fig. 3), TRP-1 and -2 synthesis were considered to coincident with toxoflavin production.

Detection of protein TRP-1 in P. glumae, $P$. gladioli and $P$. plantarii using western blots analysis

By using the antiserum, a band specific to TRP-1 was detected. The anti-TRP1 antibody reacted with a single protein band with approximately $30 \mathrm{kDa}$ on blots of SDS-PAGE separations of $P$. glumae PG9501 proteins (Fig. 4 lane 2) and TRP-1 protein (Fig. 4 lane 1). Similarly, one protein band was detected on blots of SDS-PAGE separations of toxoflavin-producing $P$. gladioli (Fig. 4 lane 7$)$. The antibodies did not react with proteins from $P$. glumae Tn5 mutants that were unable to produce toxin (Fig. 4 lane $4-\dot{6}$ ) and from toxin non-producing strains of $P$. gladioli (lane 8 ) and P. plantarii (lane 9). The anti-TRP1 antibodies did not react with TRP-2 protein.

\section{DISCUSSION}

All non-toxigenic mutants of $P$. glumae, generated by Tn 5 mutagenesis, contained Tn5 insertions in chromosomal DNA, and caused little rice seedling rot. These results suggest that toxoflavin production must be important in the virulence of $P$. glumae and may contribute significantly to lesion expansion in rice plants as previously described ${ }^{5,12}$.

When proteins from washed cell suspensions of wildtype strains of $P$. glumae were separated by 2D-PAGE, we identified two proteins designated as TRP-1 and TRP-2. These proteins were not detected on 2D-PAGE of $\mathrm{Tox}^{-}$mutants. Spontaneously generated $\mathrm{Tox}^{-}$isolates did not produce these proteins either (data not shown). In order to confirm the contribution of TRP-1 and -2 to toxin production, the electrophoretic patterns of proteins synthesized at several growth phases and temperature for culture were compared.

The synthesis of TRP-1 and - 2 was confined to the late exponential phase of growth, coinciding with the initiation of toxoflavin production during the late exponential to early stationary phases of bacterial growth. The synthesis of such proteins has been known to occur in the late phase of culture in several other bacteria ${ }^{7)}$ and yeasts. In Escherichia coli some of the lipid utilizationassociated proteins were significantly induced in the stationary phase ${ }^{1)}$. In yeast cells, a postexponential protein, designated p35, was synthesized only during the post-diauxic and stationary phases ${ }^{3)}$. And in Streptomyces scabies, the est mRNA and esterase were detected only when the culture has reached the late log or early stationary phases of growth ${ }^{13)}$. A similar regulation can be expected for TRP-1 and -2 expression.

The production of the toxin by $P$. glumae was also temperature regulated. $P$. glumae grew abundantly over a wide temperature range, whereas toxin production was limited to 30 to $40^{\circ} \mathrm{C}$. No detectable amounts are produced at other temperatures. When grown in King's $\mathrm{B}$ liquid medium over $30^{\circ} \mathrm{C}$, TRP-1 and -2 synthesis increased (data not shown). Similarly, Ashbya gossypii grew abundantly over a wide temperature range, but riboflavin production was limited to a narrow range below the growth optimum $\left(26-28^{\circ} \mathrm{C}\right)^{2}$. . In addition, riboflavin was also biosynthesized in a stationary phase. Toxoflavin may resemble riboflavin not only in its structure, but in its biosynthetic regulation.

The anti-TRP1 antibodies reacted with a single protein band of approximately $30 \mathrm{kDa}$ on blots of SDSPAGE separations of only those strains able to produce toxoflavin. The conservation of the TRP-1 protein among these strains may suggest that this protein performs an important function in producing toxoflavin.

At present, our discussion is limited because we have no direct evidence for the involvement of TRP-1 and -2 in toxin synthesis. However, we presume that the TRP-1 protein may function in toxin biosynthesis or in selfprotection from its toxin. The function of TRP-2 may be similar to TRP-1, since both proteins were synthesized under same culture conditions. Further experiments will be performed to test these ideas.

The N-terminal amino acid of these proteins should be sequenced so that probes for cloning the genes may be synthesized. Their coding region and reading frame should be then identified to elucidate the function of the proteins, TRP-1 and -2 .

We thank Dr. H. Hirano (Yokohama City University) for his support in 2D-PAGE.

\section{Literature cited}

1. Blomberg, L., Gustafsson, L., Cohen, P.S., Conway, P.L. and Blomberg, A. (1995). Growth of Escherichia coli $\mathrm{K} 18$ in piglet ileal mucus: protein expression as an indicator of type of metabolism. J. Bacteriol. 177 : 66956703.

2. Demain, A.L. (1972). Riboflavin oversynthesis. Annu. Rev. Microbiol. 369-388.

3. Fuge, E.K., Braun, E.L. and Werner-Washburne, M. (1994). Protein synthesis in long-term stationary-phase culture of Saccharomyces cerevisiae. J. Bacteriol. 176 : 5802-5813.

4. Hirano, H. (1982). Varietal differences of leaf protein profiles in mulberry. Phytochemistry $21: 1513-1518$.

5. Iiyama, K., Furuya, N., Takanami, Y. and Matsuyama, N. (1995). A role of phytotoxin in virulence of Pseudomonas glumae. Ann. Phytopathol. Soc. Jpn. 61 : 470-476.

6. King, E.O., Wood, M.K. and Raney, D.E. (1954). Two simple media for the demonstration of pyocyanin and fluorescein. J. Lab. Clin. Med. 44 : 301-307.

7. Kolter, R., Siegele, D.A. and Tormo, A. (1993). The stationary phase of the bacterial life cycle. Annu. Rev. Microbiol. 47 : 855-874.

8. Machlowitz, R.A., Fisher, W.P., Mackay, B.S., Tytell, A.A. and Charney, J. (1954). Xanthothricin, a new 
antibiotic. Antibiot. Chemother. 4 : 259-261.

9. Maniatis, T., Fritsch, E.F. and Sambrook, J. (1982). Molecular Cloning : A Laboratory Manual, Cold Spring Harbor Laboratory, Cold Spring Harbor, New York.

10. Nishiyama, K. and Ezuka, A. (1977). Rough-colony of Pseudomonas coronafaciens var. atropurpurea obtained from diseased leaves of ryegrasses. Ann. Phytopathol. Soc. Jpn. 43 : 426-431 (in Japanese).

11. O'Farrell, P.H. (1975). High resolution two-dimensional electrophoresis of proteins. J. Biol. Chem. 250 : 40074021.

12. Sato, Z., Koiso, Y., Iwasaki, S., Matsuda, I. and Shirata, A. (1989). Toxins produced by Pseudomonas glumae. Ann. Phytopathol. Soc. Jpn. 55 : 353-356 (in Japanese).

13. Schottel, J.L., Hale, V. and Babcock, M.J. (1992). Regulation and secretion of an extracellular esterase from Streptomyces scabies. Gene 115 : 27-31.

14. Simon, R., Priefer, U. and Puhler, A. (1983). A broad host range mobilization system for in vivo genetic engineering. Bio/Technology 1 : 784-791.

15. Simon, R., O'Connell, M., Labes, M. and Puhler, A. (1986). Plasmid vectors for the genetic analysis and manipulation of Rhizobia and other Gram-negative bacteria. Methods Enzymol. 118: 640-659.

16. van Veen, A.G. and Mertens, W.K. (1934). Die giftstoffe der sogenannten bongkrek-vergiftungen auf Java. Recl. Trav. Chim. 53 : 257-266.

17. van Veen, A.G. and Mertens, W.K. (1934). Das toxoflavin der gelbe giftstoff der bongkrek. Recl. Trav. Chim. 53 : 398-404.

\section{和 文 摘 要}

鈴木文彦・朱 亜峰・澤田宏之・松田 泉：イネもみ枯細菌病 菌の毒素産生関連タンパク質の特定

イネもみ枯細菌病菌 (Pseudomonas glumae) の毒素, トキソ フラビンの産生性に特異的な 2 種のタンパク質を特定すること ができた。トランスポゾン突然変異誘発法で作出した毒素非産 生変異株はイネ幼苗に対して生育阻害作用をほとんど示さず, 病原力をほ核喪失していた。この結果から毒素が本菌の病原力 と密接に関連していることが示された。さらに毒素の産生性に 特異的なタンパク質を探索するため, 野生株と毒素非産生株を 供試して二次元電気泳動法でタンパク質の泳動パターンを比較 したところ, 変異株では 2 つの酸性タンパク質, TRP-1, TRP 2 を欠失していた。本菌を振とう培養すると, 毒素は培養初期に は検出されず, 対数増殖期の後期から定常期の初期にかけて初 めて検出されることに着目して，これらのタンパク質について も培養中の各ステージでの発現を調べた。その結果, これらの夕 ンパク質は対数増殖期の後期から定常期の初期に初めて検出さ れ, 毒素が初めて検出される時期とよく一致していた。また, TRP-1 抗体を用いたウエスタン解析により, P. glumae, P. gladioli, および P. plantarii の各菌株について TRP-1 の検出を 行ったところ, TRP-1 は毒素産生能を有する P. glumae, P. gladioli の菌株においてのみ検出された。 